\title{
Correlation of low body mass index and albumin level with the presence of liver dysfunction in newly diagnosed tuberculosis patients
}

\author{
Sriyanty Sadsyam ${ }^{1 *}$, Yulia Yusrini Djabir1, Arif Santoso ${ }^{2}$ \\ ${ }^{1}$ Faculty of Pharmacy, Hasanuddin University, Makassar, Indonesia. \\ 2 Faculty of Medical, Hassanudin University, Makassar, Indonesia.
}

\section{DOI: https://doi.org/10.29303/sjp.v2i2.105}

\section{Article Info}

Received : 2021-06-01

Revised : 2021-09-06

Accepted : 2021-09-08

\begin{abstract}
Tuberculosis (TB) patients often experience reduced appetite or nutritional malabsorption leading to malnutrition, which manifests in excessive loss of muscle mass and low body mass index (BMI). Patients with protein malnutrition is associated with increased risk of drug-induced liver injury and may require a close monitoring during the course of antituberculosis (AT) treatment. The purpose of this study was to determine the correlation of low body mass index and albumin level with liver dysfunction in patients newly diagnosed with $\mathrm{TB}$ prior to receiving AT drugs. This study is a nonexperimental observational study with consecutive sampling technique by following a descriptive analytic design (cohort study). The subjects were patients in the National Lung Health Center Makassar who are newly diagnosed with TB and have not received any AT drug. The BMI data and blood samples were collected and analyzed to obtain Alanine aminotransferase (ALT), Aspartate aminotransferase (AST), and Albumin levels. It was found that out of 22 total patients, $3(14 \%)$ of the TB patients experienced liver dysfunction characterized by high level of ALT and AST levels. Both patients had normal levels of albumin despite one of them had a low BMI. The statistical showed no correlation between the low BMI or albumin level with the presence of liver dysfunction. It is concluded that the presence of liver dysfunction is not correlated with low BMI or albumin level in newly diagnosed TB patients, and hence, are not considered as independent risk factors of liver dysfunction in this population.
\end{abstract}

Keywords: Tuberculosis, BMI, Albumin

Citation: Sadsyam, S., Djabir, Y. Y., \& Santoso, A. (2021). Correlation of low body mass index and albumin level with the presence of liver dysfunction in newly diagnosed tuberculosis patients. Sasambo Journal of Pharmacy, 2(2), 51-54. doi: https://doi.org/10.29303/sjp.v2i2.105

\section{Introduction}

Tuberculosis (TB) is a highly contagious disease caused by Mycobacterium tuberculosis infection that can result in passive and latent infections or active and progressive diseases (Bharadwaj et al., 2016). TB patients often experience reduced appetite and nutritional malabsorption leading to excessive loss of muscle mass as a result of protein malnutrition (Bhargava et al., 2013). Malnutrition mostly manifests in low body mass index (BMI) in TB patients, which can be calculated from body weight in kilograms divided by height in meters squared
(Borgdorff et al., 2020). Several literatures have highlighted the importance of nutritional status on the success rate of the TB therapy (Dotulong et al., 2015; Gounden et al., 2020). Lower body mass index has been found to be an independent risk factor of higher mortality rate in TB patients (Gupta et al., 2009; Karyadi et al., 2000).

There are some biomarkers that is considered as an indicator of malnutrition, one of them is plasma albumin level. However, several studies have shown that the presence of malnutrition is not always accompanied by low plasma albumin level, therefore it 
is not a good indicator of malnutrition (Keller, 2019; Kemenkes, 2014). Moreover, low plasma albumin level or hypoalbuminemia may also depict other condition, such as chronic liver failure, kidney failure, skin damage due to extensive burns, and intestinal damage (Kenedyanti \& Sulistyorini, 2017). Since fifty percent of plasma albumin is synthetized in the liver, the plasma level of albumin is also influenced by healthy liver function.

A successful eradication of TB infection requires the completion of the six-month regimen of antituberculosis therapy. However, antituberculosis treatment has a serious adverse effect, including hepatotoxicity (Khalili et al., 2009). Hepatotoxicity incidence is around $30 \%$ in TB patients and it is highly dependent on host susceptibility (Knechel 2009). The incidence of hepatotoxic due to AT drug therapy tends to occur in patients who have had a liver disorder before therapy and patients with a low body mass index (Lay et al., 2017). Therefore, the purpose of this study was to determine the correlation of low body mass index and albumin level with liver dysfunction in newly diagnosed TB patients at National Lung Health Center Makassar. The result of this study may emphasize a close monitoring of patient condition to ensure the safety use of antituberculosis treatments in TB patients.

\section{Materials and Methods}

This study is an observational non-experimental consecutive sampling study by following a descriptive analytic design (cohort study).

The subjects were adult patients ( $>18$ years old) newly diagnosed with tuberculosis at the National Lung Health Center Makassar during the period of March June 2020. The TB patients have not received any type of anti-tuberculosis drugs previously.

The study protocol was performed in accordance to institutional human research ethical protocols. Patients' data was collected after patients have got a brief explanation about the study and have signed an informed consent for obtaining blood samples. The patient's detail such as gender, age, occupation, body mass index, body weight and height, occupation were collected using a questionnaire. Blood analysis was carried out to obtain Alanine aminotransferase (ALT), Aspartate aminotransferase (AST), and Albumin levels.

Statistical analysis was performed using an SPSS program (IBM Statistics) version 24 . The data correlation between patients' demography and plasma biomarker levels were analyzed using Pearson and Spearman correlation tests.

\section{Result and Discussion}

Patients' susceptibility to liver dysfunction and even hepatotoxicity may or may not be influenced by its condition prior to receiving the antituberculosis therapy. Table 1 presents the demographics of patients participated in this study, which include the gender, age, body weight, occupation, body mass index and qualification.

Table 1. The demographic data of new TB patients admitted to the National Lung Health Centre in Makassar.

\begin{tabular}{|c|c|c|}
\hline & Categories & Patient number $(\mathrm{n}, \%)$ \\
\hline \multirow{2}{*}{ Gender } & Male & $10(45 \%)$ \\
\hline & Female & $12(55 \%)$ \\
\hline \multirow{3}{*}{$\begin{array}{l}\text { Age } \\
\text { (years old) }\end{array}$} & $18-35$ & $10(46 \%)$ \\
\hline & $36-60$ & $11(50 \%)$ \\
\hline & $61-80$ & $1(4 \%)$ \\
\hline \multirow{4}{*}{$\begin{array}{l}\text { Body weight } \\
(\mathrm{kg})\end{array}$} & $30-40$ & $3(14 \%)$ \\
\hline & $41-50$ & $11(50 \%)$ \\
\hline & $51-60$ & $5(22 \%)$ \\
\hline & $>60$ & $3(14 \%)$ \\
\hline \multirow{5}{*}{ Occupation } & Housewives & $9(41 \%)$ \\
\hline & Civil servants & $4(18 \%)$ \\
\hline & Private sector & $3(14 \%)$ \\
\hline & Freelancers & $3(14 \%)$ \\
\hline & Students & $3(14 \%)$ \\
\hline \multirow{3}{*}{ BMI } & Underweight & $7(33 \%)$ \\
\hline & Normal & $12(55 \%)$ \\
\hline & Overweight & $3(17 \%)$ \\
\hline \multirow{4}{*}{ Qualification } & $\begin{array}{c}\text { Elementary } \\
\text { school }\end{array}$ & $4(18 \%)$ \\
\hline & $\begin{array}{c}\text { Junior high } \\
\text { school }\end{array}$ & $4(18 \%)$ \\
\hline & $\begin{array}{l}\text { Senior High } \\
\text { School }\end{array}$ & $9(41 \%)$ \\
\hline & Collage student & $5(23 \%)$ \\
\hline
\end{tabular}

There were 22 subjects participated consists of 10 males (45\%) and 12 females (55\%). Based on the table, there is no significant difference between the number of male and female patients suffering from TB. The relationship between sex and the incidence of tuberculosis in a different province of Sulawesi Island has been studied and apparently it showed TB incidence was greater in men than in women (Makhlouf et al., 2008). However, it is believed that the difference in TB rates between gender is not mainly affected by sex differences but more likely occur due to epidemiological factor of particular areas (Sidabutar et al., 2004)

Most TB patients was found within the age group of $36-60$ years are 11 people $(50 \%)$ and only 1 patient was 
an elderly (61-80 years). Based on the national survey, $\mathrm{TB}$ cases were found more in people in a productive age category (15-64 years old) compared to those who are in nonproductive age category $<15$ and $\geq 65$ years (Yen et al., 2016). The higher the prevalence in the productive age maybe resulted from increased TB transmission and exposure as they actively interact with

other people [16]. Interestingly, it is also found that most female patients were housewives $(41 \%)$, which could be transmitted from their husbands or children. Kenedyanti (2017) study has shown that housewives may be more vulnerable to TB infection due to poor ventilation at home (Shu et al., 2013). Based on the education group, the majority of respondents had lower grade of educational qualification (senior high school or lower) and only $23 \%$ had graduated from higher educational institution (college).

Predominantly, the TB patients had bodyweight between 41 and $50 \mathrm{~kg}$ (50\% of the total TB respondents). People with less body weight will be susceptible to tuberculosis due to malnutrition and lack of body immunity. Body weight is also an important demografic data when it comes to AT treatment since the dose of AT drugs is basically calculated from the patient's body weight. Based on their BMI, there were 7 people $(32 \%)$ who had a BMI $<18.5$ (underweight), 12 people $(55 \%)$ had a BMI of 18.5 - 24.9 (normal) and 3 people (14\%) had a BMI > 24.9 (overweight). People with poor nutritional status has been found to be more vunerable to TB infection (Bhargava et al., 2013). Indeed, Mycobacterium tuberculosis is more virulent to people with malnutrition since the immune system are more likely to be compromised compared to healthy people (Borgdorff et al., 2020).

Table 2. Serum ALT, AST and albumin levels of new TB patients admitted to the National Lung Health

\begin{tabular}{lccc}
\multicolumn{3}{c}{ Centre in Makassar } \\
\hline & ALT & AST & $\begin{array}{c}\text { Albumin } \\
(\mathrm{mg} / \mathrm{dl})\end{array}$ \\
\hline Mean & 25.82 & $(\mathrm{U} / \mathrm{L})$ & 4.38 \\
SD & 26.8 & 19.91 & 0.42 \\
\hline
\end{tabular}

Table 2 presents the patient's ALT, AST and albumin levels. It is shown that the mean of ALT, AST and albumin levels were all within the normal range. Normal value of ALT used in this study is $7-32 \mathrm{U} / \mathrm{l}$, AST is $6-30 \mathrm{U} / \mathrm{l}$, and Albumin is $3.5-5.2 \mathrm{mg} / \mathrm{dl}$. However, when looking at individual patients, there were 3 TB patients experienced a marked elevation of ALT and AST levels. ALT and AST are both liver transaminase enzymes that supposedly contained intracellularly within hepatocytes. Therefore, a significant increase in these enzymes level in the plasma indicates cellular damage in the liver tissue. The presence of liver dysfunction in these patients is concerning since these patients shall receive antituberculosis that may increase the risk of hepatotoxicity.

It is important to find out if patients' precondition may have a significant correlation with the presence of liver dysfunction in the patients. Table 3 reveals the number of patients who experienced an increase in ALT, AST and albumin levels based on their BMI. It was found that 1 patient from underweight category had abnormally high ALT and AST levels, while 2 patients with normal BMI had high levels of ALT and AST. When performing statistical analysis, the result shows no correlation between the BMI of patients on the presence of abnormal ALT and AST levels (Table 4). This implicate that the BMI of the patients is not a good predictor of the presence of liver dysfunction in TB patients.

Table 3. Number of new TB patients who experienced low or high levels of ALT, AST and albumin based on their body mass indices

\begin{tabular}{|c|c|c|c|c|c|c|}
\hline \multirow{2}{*}{ BMI } & \multicolumn{2}{|c|}{ ALT 1 } & \multicolumn{2}{c|}{ AST } & \multicolumn{2}{c|}{ Albumin } \\
\cline { 2 - 7 } & $\begin{array}{c}\text { Norm } \\
\text { al }\end{array}$ & High & $\begin{array}{c}\text { Norm } \\
\text { al }\end{array}$ & High & $\begin{array}{c}\text { Norm } \\
\text { al }\end{array}$ & High \\
\hline $\begin{array}{c}\text { Under } \\
\text { weight }\end{array}$ & $\begin{array}{c}6 \\
(27.27 \\
\%)\end{array}$ & $\begin{array}{c}1 \\
(4.54 \\
\%\end{array}$ & $\begin{array}{c}6 \\
(27.27 \\
\%)\end{array}$ & $\begin{array}{c}1 \\
(4.54 \\
\%\end{array}$ & $\begin{array}{c}7 \\
(31.81 \\
\%)\end{array}$ & $0(\%)$ \\
\hline $\begin{array}{c}\text { Norma } \\
1\end{array}$ & $\begin{array}{c}(45.45 \\
\%)\end{array}$ & $\begin{array}{c}2 \\
(9.09 \\
\%)\end{array}$ & $\begin{array}{c}10 \\
(45.45 \\
\%)\end{array}$ & $\begin{array}{c}(9.09 \\
\%\end{array}$ & $\begin{array}{c}12 \\
(54.54 \\
\%)\end{array}$ & $0(\%)$ \\
\hline $\begin{array}{c}\text { Overw } \\
\text { eight }\end{array}$ & $\begin{array}{c}(13.63 \\
\%\end{array}$ & $0(\%)$ & $\begin{array}{c}3 \\
(13.63 \\
\%\end{array}$ & $0(\%)$ & $\begin{array}{c}3 \\
(13.63 \\
\%)\end{array}$ & $0(\%)$ \\
\hline
\end{tabular}

Normal value of ALT $=7-32 \mathrm{U} / \mathrm{l}$, AST $=6-30 \mathrm{U} / \mathrm{l}$, Albumin $=3.5-5.2 \mathrm{mg} / \mathrm{dl}$

Table 4. Correlation between BMI and the presence of liver dysfunction in newly diagnosed TB patients

\begin{tabular}{ccccc}
\hline & \multicolumn{2}{c}{ Abnormal ALT } & \multicolumn{2}{c}{ Abnormal AST } \\
\cline { 2 - 5 } BMI & $\mathrm{r}$ & $\mathrm{p}$ & $\mathrm{r}$ & $\mathrm{p}$ \\
\cline { 2 - 5 } & -0.035 & 0.877 & -0.061 & 0.786 \\
\hline
\end{tabular}

Meanwhile, the albumin levels of all patients were within the normal range regardless the BMI category of the patients. This suggests that the BMI of patients did not significantly affect the albumin level of TB patients. Likewise, the presence of abnormal ALT and AST was not accompanied with lower albumin levels. This may suggest that the presence of abnormal liver function in the patients was recent since the liver still maintain albumin synthesis, and subsequently its plasma level. However, the result of this study is only applicable to TB 
patients prior to AT treatment initiation. It will be interesting to continue this study to see if after AT treatment the presence of hepatotoxicity is more pronounced in patients with liver dysfunction precondition or with lower BMI.

\section{Conclusion}

This study found no correlation between lower body mass index with the presence of liver dysfunction in newly diagnosed TB patients. The albumin level of all patients was normal and was not associated with patients' body mass index. Accordingly, BMI and albumin plasma level are not considered as independent risk factors for liver dysfunction in TB patients.

\section{References}

Bharadwaj S, Ginoya S, Tandon P, Gohel TD, Guirguis J, Vallabh H, et al. (2016). Malnutrition: Laboratory markers vs nutritional assessment. Gastroenterology report; 4(4): 272-280.

Bhargava A, Chatterjee M, Jain Y, Chatterjee B, Kataria A, Bhargava M, et al. (2013). Nutritional status of adult patients with pulmonary tuberculosis in rural central india and its association with mortality. PloS one; $8(10)$.

Borgdorff M, Nagelkerke N, Dye C, and Nunn P. (2000). Gender and tuberculosis: A comparison of prevalence surveys with notification data to explore sex differences in case detection. The International Journal of Tuberculosis and Lung Disease; 4(2): 123-132.

Dotulong J, Sapulete MR, and Kandou GD. (2015). Hubungan faktor risiko umur, jenis kelamin dan kepadatan hunian dengan kejadian penyakit tb paru di desa wori kecamatan wori. Jurnal Kedokteran Komunitas dan Tropik; 3(2): 121-126.

Gounden V, Vashisht R, and Jialal I. (2020). Hypoalbuminemia, StatPearls Publishing: Treasure Island (FL). p. Available from: https://www.ncbi.nlm.nih.gov/books/NBK526080 L

Gupta KB, Gupta R, Atreja A, Verma M, and Vishvkarma S. (2009). Tuberculosis and nutrition. Lung India : official organ of Indian Chest Society; 26(1): 9-16.

Karyadi E, Schultink W, Nelwan RH, Gross R, Amin Z, Dolmans WM, et al. (2000). Poor micronutrient status of active pulmonary tuberculosis patients in indonesia. The Journal of nutrition; 130(12): 2953-2958.

Keller U. (2019). Nutritional laboratory markers in malnutrition. Journal of clinical medicine; 8(6): 775.

Kemenkes R. Infodatin. (2014). Pusat data dan informasi kementerian kesehatan RI. Jakarta: Kementerian Kesehatan RI; 109(1): 1-8.

Kenedyanti E and Sulistyorini L. (2017) Analisis mycobacterium tuberculosis dan kondisi fisik rumah dengan kejadian tuberkulosis paru. Jurnal Berkala Epidemiologi; 5(2): 152-162.

Khalili H, Dashti-Khavidaki S, Rasoolinejad M, Rezaie L, and Etminani M. (2009). Antituberculosis drugs related hepatotoxicity; incidence, risk factors, pattern of changes in liver enzymes and outcome. DARU; 17(3): 163-167.

Knechel NA. (2009). Tuberculosis: Pathophysiology, clinical features, and diagnosis. Critical Care Nurse; 29(2): 34-43.

Lai H-H, Lai Y-J, and Yen Y-F. (2017). Association of body mass index with timing of death during tuberculosis treatment. PloS one; 12(1).

Makhlouf HA, Helmy A, Fawzy E, El-Attar M, and Rashed HAG. (2008). A prospective study of antituberculous drug-induced hepatotoxicity in an area endemic for liver diseases. Hepatology international; 2(3): 353-360.

Sidabutar B, Soedibyo S, and Tumbelaka A. (2004). Nutritional status of under-five pulmonary tuberculosis patients before and after six-month therapy. Paediatrica Indonesiana; 44(1): 21-4.

Yen Y-F, Chuang P-H, Yen M-Y, Lin S-Y, Chuang P, Yuan M-J, et al. (2016). Association of body mass index with tuberculosis mortality: A populationbased follow-up study. Medicine; 95(1).

Shu C, Lee C, Lee M, Wang JY, Yu C, and Lee L. (2013). Hepatotoxicity due to first-line antituberculosis drugs: A five-year experience in a taiwan medical centre. The International Journal of Tuberculosis and Lung Disease; 17(7): 934-939. 